\title{
Influence of current profile on the capture process of a set net
}

\author{
"TAKESHI. YAMANE, ${ }^{1}$ MASANARI. MATSUDA, ${ }^{2}$ AND TOMONORI. HIRAISHI ${ }^{3}$ \\ ${ }^{1}$ Kinki University, Nara 631-0052, Japan,yamanety@nara.kindai.ac.jp, ${ }^{2}$ Lake Biwa Museum, Kusatsu \\ 525-0001,Japan,matsuda@lbm.go.jp, ${ }^{3}$ HokkaidoUniversity,Hakodate 041-8611, \\ Japan,hiraisi@fish.hokudai.ac.jp.
}

ABSTRACT: The capture process of a set net may be closely related to physical environmental conditions such as the current profile influencing its passive catching function. In this paper, attention is focused on how the current profile change due to wind affects the capture process of a set net. To obtain basic data on the relationship between capture process and current profile near a set net, the current magnitude was recorded continuously for $30 \mathrm{~min}$ with the aid of a current meter set on the bottom. A series of sampling was done from 2 June to 17 August 2000 in the south-basin fishing ground of Lake Biwa, Japan. The catches were concentrated during a NNE and SSW current and a large quantity of catch was taken during a NNW current with a low velocity ranging from 3 to $5 \mathrm{~cm} \cdot \mathrm{s}^{-1}$. The results suggested that the amount of catch is controlled by current profile, which is therefore an important short-term factor controlling the capture process of a set net.

KEY WORDS: set net, capture process, current profile, catch variation, lake fishery.

\section{INTRODUCTION}

Various kinds of fishing gear have long been used in Lake Biwa $\left(35^{\circ} 15^{\prime} \mathrm{N}, 136^{\circ} 05^{\prime} \mathrm{E}\right)$ and, with a few exceptions such as trawl nets and a special type of dip net, almost all gear used have passive catching function. The largest passive gear in the lake fisheries is a set net (bamboo screen labyrinth "Eri") and the amount of catch by set net fishery is the second largest among the major fisheries, contributing about $25 \%$ to the total catch (2394 $\mathrm{t}$ in 1998). ${ }^{1}$ The most important catch species of this fishery is Plecoglossus altivelis. The fishes trapped in a chamber are scooped out of the water in the morning relatively soon (a few days) after the last operation. In practice, operation time differs with each fisherman. Set net has a very complex and intricate construction and its passive catching function is a very complicated process. It is common knowledge among fishermen engaged in this fishery that the wind conditions and current magnitude near a set net are very important factors affecting the amount of catch. ${ }^{2}$ This report provides information on the influence of current profile on the capture process of a set net.

\section{METHOD}

A series of sampling was done from 2 June to 17 August 2000 on the south basin fishing ground of Lake Biwa.

A current meter (ALEC ELECTRONICS LTD., COMPACT-EM, accuracy $\pm 1 \mathrm{~cm} \cdot \mathrm{s}^{-1}$ ) was set on the bottom at a depth of about $4 \mathrm{~m}$ (Fig. 1). The current magnitude and water temperature were recorded continuously for $30 \mathrm{~min}$. The catch data used in evaluation were daily set net catch obtained

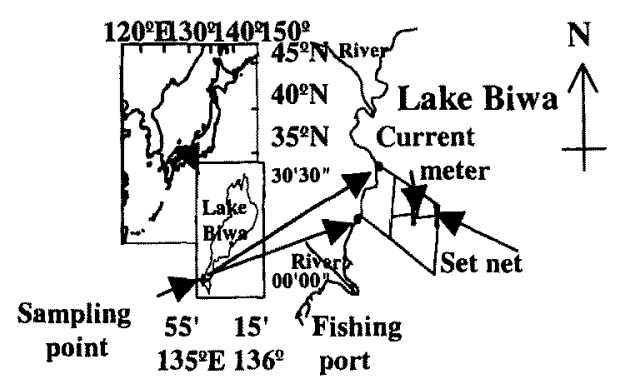


Fig. 1 Sampling point in Lake Biwa, Japan. during the observation period.

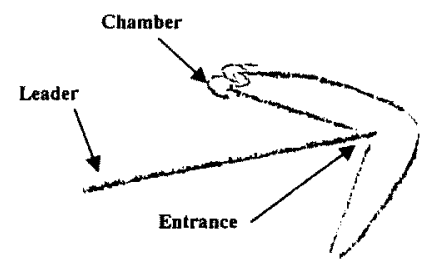

Fig. 2 Schematic diagram of set net "Eri".

\section{RESULTS}

Prevailing current for fishing period is from north-easterly (around $30^{\circ}$ ) to south-westerly (around $210^{\circ}$ ) or vice versa, the current flow almost parallel to the coast crossing the leader of a set net, and the current velocity was sometimes over $15 \mathrm{~cm} \cdot \mathrm{s}^{-1}$ at any given time (Fig. 3).

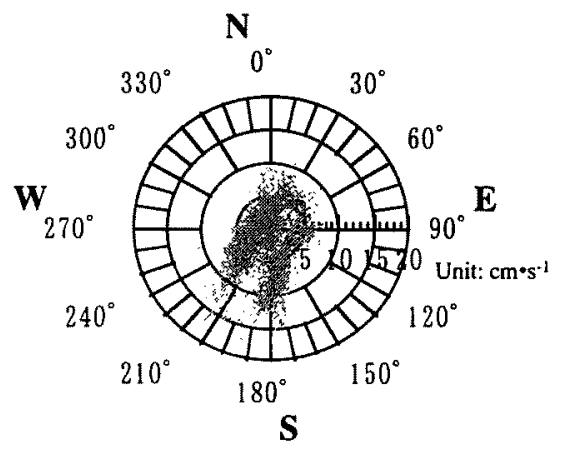

Fig. 3 Current profile (current velocity, $\mathrm{cm} \cdot \mathrm{s}^{-1}$ and direction, degree) in the area.

The representative results for an important species, $P$. altivelis, are shown as a function of current profile (direction and velocity) in Fig.4. The catches were concentrated during a $\operatorname{NNE}\left(30^{\circ}\right)$ and SSW (around $210^{\circ}$ ) current direction and large amount of catch was during a low current velocity range of from 3 to $5 \mathrm{~cm} \cdot \mathrm{s}^{-1}$.

This means that both current directions during low current velocities in the area bring a good catch. This process appears to be closely related to the habit of a species and the current profile in the area.

The prevailing current direction observed in the area was the flow running along the coastal line of the lake. The leader of the set net (Fig. 2) was to set crossing this current direction (Fig. 1). It is

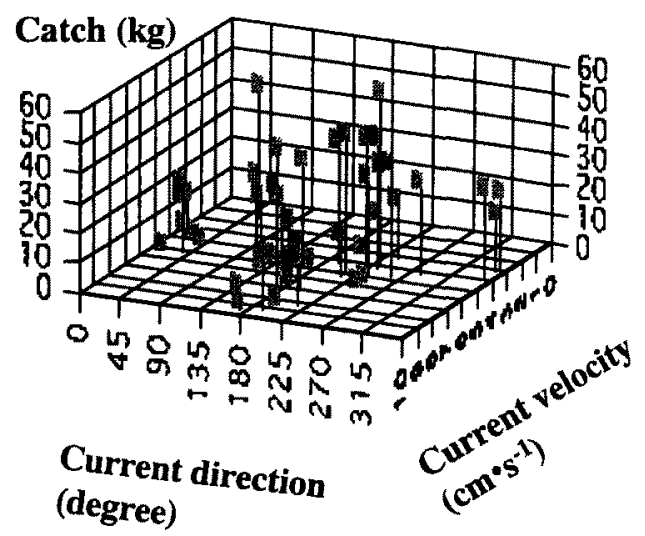

Fig. 4 Relationship between catch variation and current profile.

reasonable to assume that the fish may swim along the coast to the same current direction in a low current velocity. Assuming this picture, the current profile acts on the fish or school that moves toward the leader of the set net. During its approach process to the leader, the behavior of the fish may be controlled by the current profile. There are no detailed data about the turning point of their movement near the leader; however, if the assumption is made that most fishes or schools were transported with offshore flow, ${ }^{3}$ it is expected that most of them are guided into the interior space of the set net. The results suggest that the amount of catch is controlled by the current profile.

\section{REFERENCES}

1. Annual Statistics on Fisheries and Aquaculture Production, 1998. Statistics and Information Department, Ministry of Agriculture, Forestry and Fisheries.

2. Yamane, T. and Matsuda, M., 2001. In Lake Biwa in the 21th century, Chikyu Monthly, 264, pp 426-431 (in Japanese).

3. Yamane, T. Matsuda, M. and Kihashi, T., 2000. Proc. Fish. Engineer., 153-154 (in Japanese) 